\title{
Systematic follow-up and case management of the abnormal newborn screen can improve acceptance of genetic counseling for sickle cell or other hemoglobinopathy trait
}

\author{
Beth Kladny, MS, CGC $C^{1,3}$, Elizabeth A. Gettig, MS, CGC $C^{2}$, and Lakshmanan Krishnamurti, $M D^{3}$
}

\begin{abstract}
Purpose: Sickle cell or other hemoglobinopathy trait detected on the newborn screen provides an opportunity for genetic counseling of families at risk of having a child with a major hemoglobinopathy. However, follow-up of hemoglobinopathy trait is often fragmented and acceptance of counseling is low. We describe the results of systematic follow-up and case management of abnormal newborn screen and the effect on acceptance of counseling. Methods: From July 1997 to June 2002, families of a newborn with hemoglobinopathy trait were notified by mail. In April 2003, an intensive trait follow-up protocol including letters, telephone calls, educational videos, and genetic counseling was implemented. Demographic information and follow-up activity were documented and tracked using an electronic database. Results: From July 1997 to June 2002, 3095 families were notified by letter of a newborn with hemoglobinopathy trait and were offered genetic counseling. Of these, 165 (5.3\%) received counseling by telephone and $60(2 \%)$ underwent extended family testing. From April to December 2003, 694 families with a newborn with hemoglobinopathy trait were notified by mail. Of these, $362(52 \%)$ families were reached by telephone. Of those contacted by telephone, $92 \%$ received genetic counseling via telephone, $57 \%$ were interested in family testing, and $12 \%$ scheduled an appointment. Additionally, $27 \%$ of families were mailed an educational video. Among those declining extended family testing, $26 \%$ preferred to consult their pediatrician. Conclusions: Systematic follow-up and case management of abnormal newborn screen can improve the acceptance of genetic counseling. Genet Med 2005:7(2):139-142.
\end{abstract}

Key Words: sickle cell disease, sickle cell trait, newborn screening, abnormal hemoglobin follow-up.

Newborn screening programs began including screening for hemoglobinopathies in the United States in the 1970s. ${ }^{1}$ Since the publication of the NIH consensus statement on mandatory newborn screening for hemoglobinopathies in $1987,{ }^{2}$ there has been a widespread implementation of newborn screening programs for hemoglobinopathies. Currently 48 states and the District of Columbia offer mandatory universal newborn screening for these conditions. ${ }^{3}$ The primary purpose of this screening program has been to identify newborns with sickle cell disease and initiate penicillin prophylaxis, because this has

\footnotetext{
From the ${ }^{1}$ Department of Genetics Magee Women's Hospital, Pittsburgh, Pennsylvania; ${ }^{2}$ University of Pittsburgh Genetic Counseling Program, Pittsburgh, Pennsylvania; and ${ }^{3}$ Division of Hematology/Oncology/BMT, Children's Hospital of Pittsburgh of the University of Pittsburgh Medical Center Health System, Pittsburgh, Pennsylvania.

Lakshmanan Krishnamurti, MD, Assistant Professor Pediatrics, Division of Hematology/ Oncology/Bone Marrow Transplantation, Children's Hospital of Pittsburgh, 3705 Fifth Avenue, Pittsburgh, PA 15213.

Received: August 16, 2004.

Accepted: October 14, 2004
}

DOI: 10.1097/01.GIM.0000153662.88425.68 shown to substantially reduce the incidence of pneumococcal sepsis in infancy. ${ }^{4,5}$

In the course of screening for hemoglobinopathy disease, heterozygous carriers of abnormal hemoglobin traits are also identified, but the guidelines for follow-up are less clear and no universally accepted method of notification and counseling has proven to be effective. ${ }^{6}$ Follow-up of these families has potential benefits including notification and education of families regarding the implications of trait for the newborn, as well as identification of couples at risk for future children with disease. ${ }^{7-9}$ Many centers of care recommend face-to-face consultation to receive results as well as counseling to ensure a clear understanding of the genetic information. ${ }^{10,11}$ However, because abnormal hemoglobin traits are not believed to have adverse clinical effects on the patient, ${ }^{12,13}$ the notification and education process should provide information without creating undue anxiety. It has been suggested by some that requiring face-to-face consultation to receive results and/or postnotification counseling can be detrimental to the families. ${ }^{14}$ For this reason, we offered information and educational opportunities through a variety of methods and attempted to track which methods families chose and their reasons for those decisions. 


\section{MATERIALS AND METHODS}

The Children's Hospital of Pittsburgh Hemoglobinopathy Program holds a contract with the Department of Health, Commonwealth of Pennsylvania (PA) for follow-up of newborns identified with sickle cell disease or other hemoglobinopathy or trait hemoglobinopathy in Western Pennsylvania. The Hemoglobinopathy Program is notified electronically of newborns identified with abnormal hemoglobin traits every 2 weeks. From July 1997 to June 2002, families with a newborn with a hemoglobinopathy trait were notified by letter. A pamphlet of information was included for newborns identified with S, C, E, and Bart's hemoglobin as well as contact information for the program. Parents were reassured that heterozygous carrier for a hemoglobinopathy was not a disease, but were asked to call the center to obtain more information or to schedule an appointment for genetic counseling and extended family testing.

Beginning in April 2003, an intensive follow-up protocol for abnormal hemoglobinopathy trait that included letters, telephone calls, educational videos, and genetic counseling via telephone or in person was implemented. Demographic information and all interventions were documented and tracked using an electronic database. Families were contacted via telephone to confirm receipt of the letter and to offer an opportunity for a genetic counseling appointment at the Sickle Cell Clinic. Those parents who declined a formal genetic counseling appointment were offered the opportunity to speak to a genetic counselor via telephone as well as to receive a free educational video. Their reason for declining an appointment was recorded. At least three attempts were made to contact each family via telephone.

Genetic counseling via telephone was conducted by a single board-certified genetic counselor for all interested individuals to ensure standardized information. Genetic counseling for families in which S, C, D, or E trait was identified included a discussion on the benign nature of the hemoglobinopathy trait, autosomal recessive inheritance, confirmation of carrier status of at least one parent, risks for future pregnancies, risks for offspring of the identified child, and testing options (carrier screening/prenatal diagnosis). Genetic counseling for families in which Bart's hemoglobin was identified included a brief description of alpha-Thalassemia, the implication for the general health of the child, and futility of treatment with excess iron to treat a low-level anemia. In cases where newborn screening identified a variant hemoglobin that could not be further characterized, confirmatory testing was obtained by obtaining complete blood counts and sending blood for $\mathrm{He}$ moglobin Electrophoresis to a reference laboratory at the Mayo Clinic (Rochester, MN), and parents were reassured and offered further testing if indicated.

An educational videotape was made available to families in which the S, C, or E trait was identified. It was mailed only to families who stated that they wanted to receive it. Families were asked to complete a short telephone interview after receipt of the video. We waited at least 2 weeks to contact the families to give them enough time to view the videotape The educational video included information on red blood cells and hemoglobin, the newborn screening process, sickle cell disease versus sickle cell trait, autosomal recessive inheritance and carrier frequencies, and the genetic counseling and other resources available at the Children's Hospital of Pittsburgh Sickle Cell Program. There was also a segment from a mother of a child affected with sickle cell disease, emphasizing the importance of knowing your own and your partner's trait status.

Parents who requested an educational video were mailed the video and asked to complete a short telephone interview after receipt of the video. Families that scheduled a clinic appointment received a reminder call at least 1 day before the appointment. When an appointment was missed or canceled, at least two telephone calls were made to reschedule the patient. For those who decided not to reschedule, the reason for declining was recorded.

\section{RESULTS}

Between April 2003 and December 2003, 679 newborns were identified as heterozygous carrier of a hemoglobinopathy. Letters were mailed to all families. Of these, 27 (3\%) letters were returned as undeliverable. We attempted to contact all families by telephone and reached 362 (53\%) families. There were 92 disconnected telephone numbers and 34 families in which there was no answer and no answering machine. We left messages for 191 families, but were unable to talk to anyone. We tried all of the working telephone numbers at least three times. Of those families that were contacted, 333 (92\%) received genetic counseling via telephone.

Educational videos were sent to the 99 families who requested them. Follow-up interviews have been completed on 43 (Table 1). Of the 43 families who agreed to complete the interview, 95\% told us that the video provided additional information that answered their questions about trait. When asked whether the video decreased or increased their anxiety level, 92\% responded that it decreased anxiety. In addition, 95\% told us that the video provided additional information that answered their questions about trait. We also asked a series of general information questions, in which 93\% of respondents could tell the difference between "trait" and "disease," 93\% knew that you could not "catch sickle cell disease like a cold," and 95\% understood that parents have no control over which genes get passed onto their children.

Of the 362 families contacted by telephone, 222 were not interested in scheduling a clinic appointment. The two most common reasons for declining an appointment were that previous testing/counseling had already been performed (28\%) and a preference to receiving information through their primary care physician or pediatrician (26\%) (Table 2).

Of the 362 families reached by telephone, 140 indicated interest in scheduling an appointment. Appointments were made for 66 (47\%). Those who chose not to schedule gave several reasons, including relocation out-of-state, satisfaction 
Table 1

Follow-up interview questions from the educational video

\begin{tabular}{|c|c|c|c|}
\hline Question & $\begin{array}{l}\text { No. of Y } \\
\text { respons }\end{array}$ & $\begin{array}{l}\text { Yes } \\
\text { nses }\end{array}$ & $\begin{array}{l}\text { No. of No } \\
\text { esponses }\end{array}$ \\
\hline 1. Did you receive the video? & 43 & & 0 \\
\hline 2. Have you watched the video tape? & 43 & & 0 \\
\hline 3. Was it easy to understand? & 42 & & 1 \\
\hline 4. Did the video answer your questions? & 41 & & 2 \\
\hline $\begin{array}{l}\text { 5. Was it helpful to hear a mother tell you } \\
\text { her story? }\end{array}$ & 40 & & 3 \\
\hline $\begin{array}{l}\text { 6. Was there anything that stood out (good } \\
\text { or bad) about the video? }\end{array}$ & 20 & & 23 \\
\hline $\begin{array}{l}\text { 7. Did you feel less anxious after watching } \\
\text { the video? }\end{array}$ & 40 & & 3 \\
\hline $\begin{array}{l}\text { 8. Has anyone else in your family/friends } \\
\text { watched the video? }\end{array}$ & 16 & & 27 \\
\hline $\begin{array}{l}\text { 9. Did you tell other family members that } \\
\text { your baby has a trait? }\end{array}$ & 34 & & 9 \\
\hline General knowledge questions & $\begin{array}{l}\text { No. who } \\
\text { answered } \\
\text { correctly }\end{array}$ & $\begin{array}{l}\text { No. who } \\
\text { answered } \\
\text { incorrectly }\end{array}$ & $\begin{array}{l}\text { d No. } \\
\text { d ly unsure }\end{array}$ \\
\hline $\begin{array}{l}\text { 1. Did the video make it clear that there is a } \\
\text { difference between sickle cell trait and } \\
\text { sickle cell disease? This is not a question } \\
\text { that can be answered correctly or } \\
\text { incorrectly }\end{array}$ & 40 & 1 & 2 \\
\hline $\begin{array}{l}\text { 2. Can a child with sickle cell trait ever } \\
\text { develop sickle cell disease? }\end{array}$ & 39 & 2 & 2 \\
\hline $\begin{array}{l}\text { 3. Do both parents have to have sickle cell } \\
\text { trait for a baby to be born with sickle cell } \\
\text { disease? }\end{array}$ & 39 & 3 & 1 \\
\hline $\begin{array}{l}\text { 4. If one parent has sickle } S \text { trait and one } \\
\text { parent has hemoglobin } C \text { trait, could } \\
\text { they have a baby with disease? }\end{array}$ & 25 & 7 & 11 \\
\hline $\begin{array}{l}\text { 5. If you have sickle cell trait, could your } \\
\text { brother or sister also have sickle cell } \\
\text { trait? }\end{array}$ & 39 & 0 & 4 \\
\hline $\begin{array}{l}\text { 6. Can you choose which genes are passed } \\
\text { onto your children? }\end{array}$ & 41 & 0 & 2 \\
\hline $\begin{array}{l}\text { 7. Can you "catch" sickle cell disease like a } \\
\text { cold? }\end{array}$ & 40 & 0 & 3 \\
\hline
\end{tabular}

with the information provided by the genetic counselor via telephone, and time constraints.

\section{DISCUSSION}

The detection of sickle cell or other hemoglobinopathy trait in a newborn offers an opportunity to offer extended family testing and genetic counseling regarding sickle cell disease. However, the follow-up of sickle cell trait detected on the newborn screen is inconsistent across the country and is often inadequate. ${ }^{15}$ In the United States, 32 of 49 states that offer newborn screening for hemoglobinopathies do not offer aggressive follow-up for sickle cell trait. Only 7,669 (15\%) of the
Table 2

Reasons families declined a clinic appointment

\begin{tabular}{lcc}
\hline Reason & $\begin{array}{c}\text { No. of } \\
\text { responders } \\
(n=222)\end{array}$ & $\begin{array}{c}\text { Percent of } \\
\text { responders }\end{array}$ \\
\hline Parents already received testing & 64 & 29 \\
$\begin{array}{l}\text { Family prefers contact to be with the } \\
\text { pediatrician/PCP }\end{array}$ & 58 & 26 \\
$\begin{array}{l}\text { No reason given } \\
\text { No interest in further education/counseling }\end{array}$ & 27 & 12 \\
We answered all of their questions via telephone/ \\
$\quad$ letter
\end{tabular}

50,491 U.S newborns detected to have sickle cell trait in the year 2000 are reported to have undergone confirmatory testing. ${ }^{16}$ The nature of family testing, counseling, or its outcome is unknown. Programs for follow-up of sickle cell trait and counseling have found limited acceptance by families. ${ }^{17,18} \mathrm{Be}-$ cause the heterozygous carrier state for hemoglobinopathy does not place the infant at any risk, it is understandable that families may not perceive extended family testing and counseling a high priority. There is, therefore, a need to adopt a flexible approach to counseling and testing, taking into account the parents' convenience and general level of interest in receiving the information. We implemented an approach that includes intensive case management and the provision of professional genetic counseling in a flexible and accessible manner. We sought to provide families with multiple opportunities for different levels of information. The most basic level was notification of the baby's trait status through a letter to the family and a letter to the pediatrician of record. However, this is a passive process and requires no action on the part of the families. In fact, although we know that $97 \%$ of letters were not returned, it is impossible to determine what proportion were actually delivered to the intended recipient and were read or understood by them.

The next level was an initial telephone call in which we attempted to engage the family (primarily the birth mother), into a discussion about the information provided in the letter. At this point, the contacted family member was asked to indicate an interest in a formal clinic appointment, an educational video, or genetic counseling via telephone. This level of service required that the family member be available and willing to interact with the health care provider. One of the most significant barriers to provision of this service was the ability to locate these families, because $47 \%$ were unreachable due to disconnected telephone numbers or inability to reach anyone at the telephone number given.

Our data suggested that contact made within 3 to 4 weeks after delivery was the most effective time-frame in which to reach these families. We speculate that this could be due to the general mobility of the population, ${ }^{18,19}$ the end of maternity 
leave and return to the work environment for many mothers 6 weeks after delivery, or other factors.

Of the families that we were able to contact, $92 \%$ agreed to genetic counseling via telephone. This counseling clarified the information that was received in the notification letter and provided in-depth coverage of the basic points. The family members provided a verbal acknowledgment of understanding before the conclusion of the consultation. In addition to raising awareness of the condition, these families also received information and were able to articulate these concepts back to the counselor when questioned. Telephone consultation may have been more accepted than other forms of contact due to the immediate nature of the event ${ }^{20,21}$ and the perceived burden of scheduling and keeping a clinic appointment. ${ }^{22,23}$

Videotapes with information on sickle cell or other hemoglobinopathy trait were sent to 99 families, and follow-up interviews have been conducted on 43 of these families. All of these families indicated that they had watched the videotape and were able and willing to answer questions regarding this information. The remaining families (56) have not been interviewed because they were unable to be contacted, refused to be interviewed, or have only recently received the videotape. Access to this educational material for home-viewing may have relieved any stress of time and travel to a clinic and allowed the family to include as many family members as desired in the educational process in the comfort of their own environment. Unlike many clinic visits, in which only the mother is able to be present, the videos were viewed by husbands or partners ( $n=$ 7 ) and extended family members and friends $(n=12)$. Information regarding trait was shared with immediate family members $(n=22)$, friends $(n=7)$, and partners/husband ( $n$ $=5$ ). The information contained in the video remains available to the family if questions arise in the future.

Each of the 362 families contacted by telephone was offered the opportunity to schedule a clinic appointment for extended family testing and counseling. The majority of contacted individuals $(61 \%)$ were not interested in scheduling an appointment for various reasons. In addition, 140 (39\%) families had interest in an appointment, but only 66 (47\%) scheduled an appointment, showing an intent to receive this level of care. Individuals who attend a clinic appointment had the interest and the intent and were able to receive the highest level of clinical care and education.

In conclusion, our results indicate that an approach of intensive case management and provision of services at multiple levels can improve acceptance of genetic counseling by parents of newborns identified with a hemoglobinopathy trait. The majority of families contacted are willing to accept genetic counseling over the telephone.

\section{ACKNOWLEDGMENTS}

This was work was supported in part by Health Resources \& Services Administration Grant 6H46MC 00255-01-01

\section{References}

1. Pearson HA, O'Brien RT, McIntosh S, Aspnes GT, Yang MM. Routine screening of umbilical cord blood for sickle cell diseases. JAMA 1974;227:420-421.

2. Consensus conference. Newborn screening for sickle cell disease and other hemoglobinopathies. JAMA 1987;258:1205-1209.

3. National Newborn Screening and Genetics Resource Center: Current Newborn Screening (NBS) Conditions by State. US National Newborn Screening Status Report Updated 10/19/2004. vol. 2004. Austin, TX: NNSGRC; 2004. Available at: http://genes-r-us.uthscsa.edu/nbsdisorders.pdf. Accessed October 26, 2004.

4. Gaston MH, Verter JI, Woods G, et al. Prophylaxis with oral penicillin in children with sickle cell anemia. A randomized trial. N Engl J Med 1986;314:1593-1599.

5. Powars DR. Natural history of sickle cell disease-the first ten years. Semin Hematol 1975;12:267-285.

6. Grossman LK, Holtzman NA, Charney E, Schwartz AD. Neonatal screening and genetic counseling for sickle cell trait. Am J Dis Child 1985;139:241-244.

7. Henthorn JS, Almeida AM, Davies SC. Neonatal screening for sickle cell disorders. Br J Haematol 2004;124:259-263.

8. Rowley PT. Parental receptivity to neonatal sickle trait identification. Pediatrics 1989;83:891-893.

9. Anyane-Yeboa K. Hemoglobinopathy screening during early pregnancy. Pediatrics 1989;83:881-883.

10. Whitten CF, Thomas JF, Nishiura EN. Sickle cell trait counseling-evaluation of counselors and counselees. Am J Hum Genet 1981;33:802-816.

11. Day SW, Brunson GE, Wang WC. Successful newborn sickle cell trait counseling program using health department nurses. Pediatr Nurs 1997;23:557-561.

12. Heller P, Best WR, Nelson RB, Becktel J. Clinical implications of sickle-cell trait and glucose-6-phosphate dehydrogenase deficiency in hospitalized black male patients. N Engl J Med 1979;300:1001-1005.

13. Boyle E, Jr., Thompson C, Tyroler HA. Prevalence of the sickle cell trait in adults of Charleston Charleston County, SC. An epidemiological study. Arch Environ Health 1968;17:891-898.

14. Harris H. Follow-up of children with trait in a rural setting. Pediatrics 1989;83:876877.

15. Farrell M, Certain L, Farrell P. Genetic counseling and risk communication services of newborn screening programs. Arch Pediatr Adolesc Med 2001;155:120-126.

16. National Newborn Screening and Genetics Resource Center, National Newborn Screening Report, 2000. Austin, TX: NNSGRC, 2003. Available at: http://genes-r us.uthscsa.edu/resources/newborn/00chapters.html. Accessed October 26, 2004.

17. Miller ST, Stilerman TV, Rao SP, Abhyankar S, Brown AK. Newborn screening for sickle cell disease: When is an infant 'lost to follow-up'? Am J Dis Child 1990;144: 1343-1345.

18. Hurst D. Newborn screening for sickle cell disease and other hemoglobinopathies: Northern California's experience. Pediatrics 1989;83:868-871.

19. Diaz-Barrios V. Newborn screening for sickle cell disease and other hemoglobinopathies. New York's experience. Pediatrics 1989;83:872-875.

20. Robin A. Rationing out-patients: a defence of the waiting list. Br J Psychiatry 1976; 129:138-141.

21. Carpenter PJ, Morrow GR, Del Gaudio AC, Ritzler BA. Who keeps the first outpatient appointment? Am J Psychiatry 1981;138:102-105.

22. Canizares MJ, Penneys NS. The incidence of nonattendance at an urgent care dermatology clinic. J Am Acad Dermatol 2002;46:457-459.

23. Mallard SD, Leakeas T, Duncan WJ, Fleenor ME, Sinsky RJ. Same-day scheduling in a public health clinic: a pilot study. J Public Health Manag Pract 2004;10:148-155. 